\title{
F-Box Only Protein 11
}

National Cancer Institute

\section{Source}

National Cancer Institute. F-Box Only Protein 11. NCI Thesaurus. Code C101106.

F-box only protein 11 (927 aa, 104 kDa) is encoded by the human FBXO11 gene. This protein plays a role in substrate recognition for the ubiquitin lig ase complex. 